\title{
Effect of the juvenile hormone analogue (Admiral) on viability of eggs and postembryonic development of the soft tick Argas persicus (Oken)
}

\author{
Wafaa A. Radwan; Nadia Helmy; Noha A. Guneidy and Shimaa S. Mohammed \\ Department of Entomology, Faculty of Science, Ain Shams University
}

\section{ABSTRACT}

Treatment of one day old females (previtellogenic) of A. persicus with JHA (Admiral) showed a significant effect on viability of deposited eggs and on total mortality of post-embryonic stages. On the other hand, treatment of 3-days old females (vitellogenic) and 7-days old females (post-vitellogenic and ovulation) of $A$. persicus exhibited a highly significant effect on viability of eggs and on total mortality of post-embryonic stages (especially larval and younger nymphal instars).

The topical application of JHA (Admiral) in different doses to newly laid eggs (0-1 h POP) of A. persicus has a highly significant effect on the development of treated eggs. This was also true in case of dipping of egg masses in solution containing different doses of Admiral for 1 minute. This effect increased by increasing the dose of the hormonal material.

Key words: Argas persicus, Juvenile hormone analogue, viability of eggs, Postembryonic development

\section{INTRODUCTION}

The fowl tick, Argas (Persicargas) persicus, is a specific parasite of domestic and certain wild birds in parts of Asia, Europe, Africa and Australia. Argas persicus, as well as, other Argas species serve as vectors of several agents infectious to human and birds (Hoogstraal, 1985).

Today, the problems in Argas persicus control are mortality among nontarget organs, resistance among pest population and health hazard caused by acaricides, miticides, insecticides and other chemicals. Therefore it seems urgent to search for effective, selective and safe compounds to control these pests.

Evidence has accumulated that ecdysteroids and juvenile hormones (JHs), known to regulate development in insects, are also present in ticks (Pound and Oliver, 1979). These hormones or their analogues have been suggested as agents for the control of insect pests, and it is conceivable that a similar strategy might prove useful for control of ticks.

Several investigations indicate that ticks are sensitive to juvenile hormone analogues (JHAs). Low's-mixture (transdihydrochloride of ethyl farnesoate) altered egg development when applied to engorged female Ixodes persulactus Schulze (Kantakova et al., 1976), and was toxic to unfed females (Loffe et al., 1977).

Hydroprene (Altozar) [ethyl- (2E, 4E) -3, 7, 11 - trimethyl - 2, 4dodecadienoate] delayed I. ricinus (L.) metamorphosis and caused high mortality of treated eggs and newly emerging larvae (Loffe and Uspensky, 1979). Hatch of eggs from Hyalomma (H.) dromedarii Koch and D. variabilis was reduced after topical application on the first day of oviposition with three juvenile hormone analogues (Bassal, 1974; McDaniel and Oliver, 1978). 
Egg hatch was also reduced after treating engorged female B. microplus with hydroprene, kinoprene (ZR 777), farnesyl methyl ether, farnesynic acid and methoprene (Mansingh and Rawlins, 1977).

Herein, we report the effect of juvenile hormone analogue (Admiral) on the viability of eggs and postembryonic development of the fowl tick, Argas (persicargas) persicus.

\section{MATERIALS AND METHODS}

\section{Ticks:}

The soft tick Argas persicus (Oken) was collected from a domestic chicken house at Banisweif Governorate, Egypt. The ticks were colonized in the laboratory at $27^{\circ} \mathrm{C} \pm 1 \& 75 \%$ R.H. and 16 hrs. day light (as described by Kaiser, 1966).

\section{Treatment:}

The juvenile hormone analogue (Admiral, from Sumitomo company), was provided by Prof. Reda Fadeel, Ain-Shams University, Faculty of Science.

Admiral 10\% (technicals grade), common name: pyriproxyfen "4-phenoxyphenol (RS)-2-(2-pyridyloxy) propyl ether".

\section{Female treatment:}

The hormonal material was administered topically with micro-syringe on the ventral side of the posterior half of the female body. Fifteen $\mu \mathrm{g}$. of the hormonal material was used per each female. The hormonal material was applied to female ticks at different periods of the reproductive cycle. Pairs of treated females and normal males were kept separately at $27^{\circ} \mathrm{C} \pm 1$ and $75 \%$ R.H. in an insectary. Eggs were collected daily to follow their hatchability.

\section{Egg treatment:}

Newly laid eggs $(0-1 \mathrm{~h})$ postoviposition (POP) were treated topically by 1.5 , $15,150, \& 1500 \mu \mathrm{g}$ of the hormonal material in $15 \mu$ lacetone / 30 eggs respectively. The hormonal material was applied topically by micro-pipette directly on eggs.

In dipping technique, newly laid eggs (0-1 h) POP were immersed in 100-200 $\mu \mathrm{l}$ acetone solution containing one of four different doses $(100,150,170, \& 200 \mu \mathrm{g} /$ 30 eggs) of Admiral. The experiment was repeated 5 times $(30 \times 5)$ and eggs were dipped for 1 minute in each solution. Eggs used as control were treated with appropriate amount of pure acetone.

\section{Evaluation of hormonal effect:}

The effect of the hormonal material on the viability of eggs was determined by counting the number of unhatched eggs $192 \mathrm{~h}$ after their treatment (about 24 - hours after the time they would normally hatch).

Late effect of the hormonal material on post-embyonic development was also followed for the first generation. Hatched larvae were placed in rearing tubes to determine percentage mortality of successive larval, nymphal and adult stages.

\section{Statistical Analysis:}

The obtained data were manipulated statistically with the help of Prov Anova in SAS (SAS Institute 1996), in which the equation of the standard deviation, standard errors, T-statistic values and probabilities $(\mathrm{P})$ were used. 


\section{RESULTS}

1. Effect of a selected dose of JHA (Admiral) on viability of eggs laid by Argas persicus females treated at different periods of the reproductive cycle:

In this experiment, females on the day of emergence, 3-days old females and females just before egg laying ( 7 - days old), received a dose of $15 \mu \mathrm{g}$ of the hormonal material / female. The eggs from normal and treated females were examined for their hatchability.

Data in Table (1) indicate that females treated on the day of emergence with Admiral exhibit a significant effect $(\mathrm{P}<0.05)$ on viability of eggs laid, where percentage of unhatched eggs was $16.7 \pm 1.1$ for treated females compared with $1.8 \pm$ 0.4 for control ones.

On the other hand treatment of 3 - days old females has a highly significant effect $(\mathrm{P} \leq 0.01)$ on the viability of eggs laid, where the percentage of unhatched eggs was $33.5 \pm 4.7$ for treated compared with $3.1 \pm 0.5$ for the control.

Treatment of 7 - days old females also has a highly significant effect $(\mathrm{P} \leq$ 0.01 ) on the viability of eggs laid, where percentage of unhatched eggs was $27.2 \pm 3.1$ for treated females compared with $2.3 \pm 0.3$ for the control.

Table (1): Effect of selected dose (15 $\mu \mathrm{g} /$ female) of JHA (Admiral) on viability of eggs laid by Argas persicus females treated at different periods of reproductive cycle.

\begin{tabular}{|c|c|c|c|c|c|c|c|c|}
\hline \multirow{2}{*}{$\begin{array}{ll}\text { Time } & \text { of } \\
\text { treatment } \\
\text { females }\end{array}$} & \multicolumn{4}{|c|}{ Control } & \multicolumn{4}{|c|}{ Treated } \\
\hline & 1 & 2 & 3 & 4 & 1 & 2 & 3 & 4 \\
\hline $\begin{array}{l}\text { Treatment at day } \\
\text { of emergence }\end{array}$ & $\begin{array}{r}97.1 \\
+4.1\end{array}$ & $\begin{array}{r}95.3 \\
+4.1\end{array}$ & $\begin{array}{r}1.9 \\
+0.4\end{array}$ & $\begin{array}{c}1.8 \\
+0.4\end{array}$ & $\begin{array}{r}85.0 \\
+2.7\end{array}$ & $\begin{array}{r}71.0 \\
+3.2\end{array}$ & $\begin{array}{r}14.0 \\
+0.6\end{array}$ & $\begin{array}{r}16.7 \\
+1.1\end{array}$ \\
\hline $\begin{array}{l}\text { Treatment at } 3^{\text {rd }} \\
\text { day of } \\
\text { emergence }\end{array}$ & $\begin{array}{r}93.0 \\
+3.7 \\
\end{array}$ & $\begin{array}{r}90.1 \\
+3.8\end{array}$ & $\begin{array}{c}3.0 \\
+0.5\end{array}$ & $\begin{array}{c}3.1 \\
+0.5\end{array}$ & $\begin{array}{r}83.9 \\
+2.1\end{array}$ & $\begin{array}{l}56.0 \\
+4.3\end{array}$ & $\begin{array}{r}27.9 \\
+3.8\end{array}$ & $\begin{array}{r}33.5 \\
+4.7\end{array}$ \\
\hline $\begin{array}{l}\text { Treatment at } 7^{\text {th }} \\
\text { day of } \\
\text { emergence }\end{array}$ & $\begin{array}{r}80.0 \\
+2.4 \\
\end{array}$ & $\begin{array}{r}78.2 \\
\pm 2.5\end{array}$ & $\begin{array}{c}1.8 \\
\pm 0.2\end{array}$ & $\begin{array}{c}2.3 \\
\pm 0.3\end{array}$ & $\begin{array}{l}77.1 \\
\pm 1.6\end{array}$ & $\begin{array}{l}56.0 \\
\pm 2.7\end{array}$ & $\begin{array}{l}20.9 \\
\pm 2.4\end{array}$ & $\begin{array}{r}27.2 \\
\pm 3.1\end{array}$ \\
\hline
\end{tabular}

(1) Average No. of eggs laid

(2) Average No. of hatched eggs

(3) Average No. of unhatched eggs

(4) $\%$ unhatched eggs

2. Late effect of JHA (Admiral) on postembryonic development of eggs obtained from Argas persicus females treated at different periods of the reproductive cycle:

From Fig. (1), it could be observed that the percentage of total mortality of postembryonic stages was $16.4 \%$ for females treated on day of emergence compared with $7.2 \%$ for the control, where there was a significant late effect $(\mathrm{P}<0.05)$ on mortality of postembryonic stages (larval and nymphal instars).

Treatment of females on $3^{\text {rd }}$ day of emergence with Admiral has a highly significant late effect $(\mathrm{P} \leq 0.01)$ on postembryonic stages; where percentage of total mortality was $29.8 \%$ compared with $7.2 \%$ for the control. This effect was most pronounced $(\mathrm{P} \leq 0.01)$ during larval instar and $1^{\text {st }}$ nymphal instar, where percentage mortality were $8.9 \pm 1.1$ and $7.8 \pm 1.1 \%$, respectively compared with $1.9 \pm 0.3$ and $1.7+0.3$ for the control ticks.

Treatment of females on $7^{\text {th }}$ day of emergence with admiral also has a highly significant late effect $(\mathrm{P} \leq 0.01)$ on postembryonic stages, where percentage of total 
mortality was $21 \%$ compared with $7.2 \%$ for the control. This effect was most pronounced on larval and nymphal instars $(\mathrm{P} \leq 0.01)$ especially first and third nymphal instars, where the percentage of mortality were $5.3 \pm 1.1,5.6 \pm 1.1$ and $6.2 \pm$ 1.2 respectively compared with $1.9 \pm 0.3,1.7 \pm 0.3$ and $1.8 \pm 0.3$ for the control ticks.

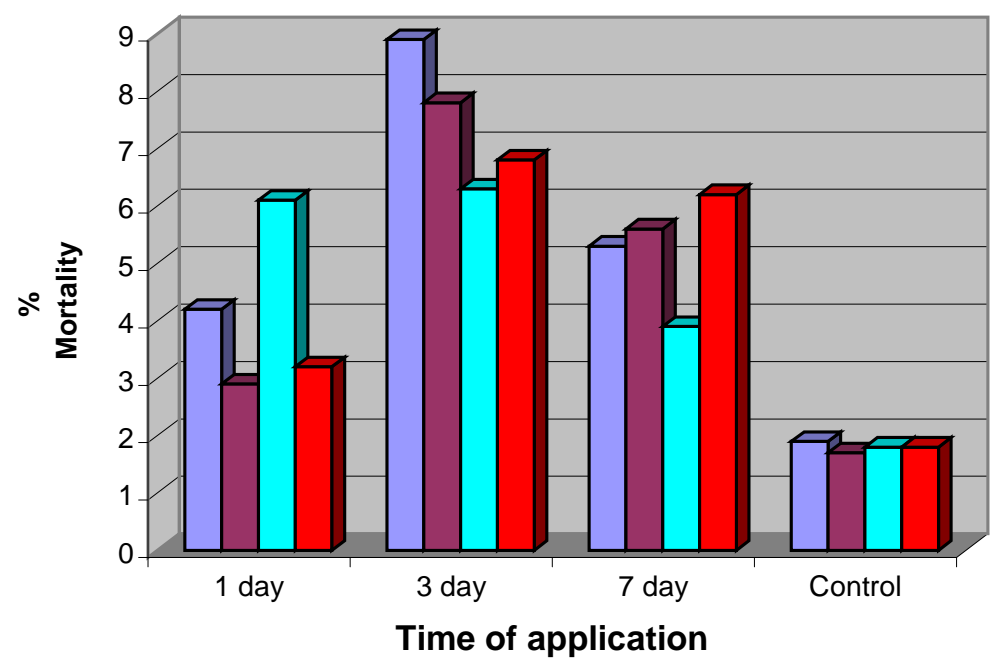

口Larval instar

$\square$ 1st nymphal instar

$\square$ 2nd nymphal instar

■rd nymphal instar

Fig. (1)

Fig. (1): Late effect of Admiral on postembryonic development of eggs laid by Argas persicus females treated at different periods of reproductive cycle.

\section{Effect of direct application of JHA (Admiral) on viability of eggs:}

\subsection{Topical application:}

The results from Table (2) indicated that there is a highly significant effect on treated eggs $(\mathrm{P} \leq 0.01)$ and the effect is dose dependent, where the percentage of unhatched eggs increase as dose increases. The effect is most pronounced in case of using 150 and $1500 \mu \mathrm{g}$ where percentage of unhatched eggs were $85.9 \pm 1.1$ and 95.9 \pm 0.5 respectively.

Table (2): Hatchability of Argas persicus eggs treated topically with different doses of JHA (Admiral) at day of deposition.

\begin{tabular}{|c|c|c|c|c|}
\hline $\begin{array}{c}\text { Dose in } \mu \mathrm{g} / \\
\text { 30 eggs }\end{array}$ & $\begin{array}{c}\text { No. of treated } \\
\text { eggs / batch }\end{array}$ & $\begin{array}{c}\text { Av. No. of } \\
\text { hatched eggs }\end{array}$ & $\begin{array}{c}\text { Av. No. of } \\
\text { unhatched eggs }\end{array}$ & \% unhatching \\
\hline 1.5 & 30 & $27.8 \pm 0.1$ & $22.0 \pm 0.1$ & $7.2 \pm 0.6$ \\
\hline 15 & 30 & $25.2 \pm 0.1$ & $4.8 \pm 0.1$ & $15.9 \pm 0.5$ \\
\hline 150 & 30 & $4.2 \pm 0.3$ & $25.8 \pm 0.3$ & $85.9 \pm 1.1$ \\
\hline 1500 & 30 & $1.2 \pm 0.1$ & $28.8 \pm 0.1$ & $95.9 \pm 0.5$ \\
\hline Control & 30 & $29.0 \pm 0.1$ & $1.0 \pm 0.1$ & $3.3 \pm 0.1$ \\
\hline
\end{tabular}

\subsection{Dipping technique:}

Results from Table (3) showed that dipping the eggs in acetone solutions containing 100, 150, 170 and $200 \mu \mathrm{g}$ of the hormonal material has a highly significant 
effect on eggs, where percentage of unhatched eggs were $8.6 \pm 0.8,20.6 \pm 1.4,33.3 \pm$ 0.9 and $86.6 \pm 0.9$ respectively compared with $6.6 \pm 0.9$ for the control. This effect was dose-dependent, where percentage of unhatched eggs increases with the increase of dose.

Table (3): Hatchability of Argas persicus egg treated by dipping in solution with different doses of JHA (Admiral) at day of deposition:

\begin{tabular}{|c|c|c|c|c|}
\hline $\begin{array}{c}\text { Dose in } \mu \mathrm{g} / \text { egg } \\
\text { mass }(30 \text { eggs) }\end{array}$ & $\begin{array}{c}\text { No. of treated eggs } \\
\text { per each replicate } \\
(30 \times 5)\end{array}$ & $\begin{array}{c}\text { Av. No. of hatched } \\
\text { eggs from five } \\
\text { replicates }\end{array}$ & $\begin{array}{c}\text { Av. No. of } \\
\text { unhatched eggs }\end{array}$ & $\%$ unhatched \\
\hline 100 & 30 & $26.6 \pm 0.2$ & $3.4 \pm 0.2$ & $8.6 \pm 0.8$ \\
\hline 150 & 30 & $23.8 \pm 0.4$ & $6.2 \pm 0.4$ & $20.6 \pm 1.4$ \\
\hline 170 & 30 & $20.0 \pm 0.3$ & $10.0 \pm 0.3$ & $33.3 \pm 0.9$ \\
\hline 200 & 30 & $4.0 \pm 0.2$ & $26.0 \pm 0.2$ & $86.6 \pm 0.9$ \\
\hline Control & 30 & $28.0 \pm 0.2$ & $2.0 \pm 0.2$ & $6.6 \pm 0.9$ \\
\hline
\end{tabular}

\section{DISCUSSION}

1. Effect of a selected dose of JHA (Admiral) on viability of eggs laid by females treated at different periods of the reproductive cycle:

Since tick oogenesis is classified into three stages, previtellogenic, vitellogenic stage (at $3^{\text {rd }}$ day after emergence), and ovulation stage (just before egg laying) (Diehl et al., 1982); Therefore findings of the present study indicate that vitellogenic females of Argas persicus are the most sensitive to effect of the hormonal material, followed by postvitellogenic females during ovulation, while previtellogenic females are the least sensitive.

Reduction of fertility of reproducing females by treatment with juvenile hormone analogues was also reported in different species of blood sucking insects and ticks; Cimex lectularuis (Shaarawi et al., 1981) after treatment with high doses of JHA (ZR - 515), just before egg laying. This reduction may be due either to an effect on some later steps in the differentiation and function of follicular cells (Gelbic and Sehnal, 1973) or to derangement of humoral control of oviposition (Matolin and Gelbric, 1975), in Ctenocephalides felis after treatment with JHA (CGA - 255'728) (Rosa et al., 2000), in Boophilus microplus after treatment with six JHAs (Mansingh and Rawlins, 1977), Amblyomma americanum (Teel et al., 1996) and in Hyalomma dromedarii after topical application on $1^{\text {st }}$ day of oviposition with three JHAs (Bassel, 1974).

Similar to the condition of the fowl tick, Argas persicus, the maximal sensitivity of females Musca domestica to ovicidal effect of JHA (Sumilarv) has been observed during vitellogenesis and ovulation (Shambaky et al., 1993).

During the reproductive cycle, difference in the sensitivity of female Argas persicus to Admiral could be correlated to the difference in the activity of neurosecretory cells of the treated females and to the titer of the endogenous gonadotropic hormone that are synthesized by synganglion and released into the haemolymph of these females. The synganglion produce a gonadotropic hormone which stimulate the onset of vitellogenesis in the ovaries of Argas hermanni (Shanbaky et al., $1990 \mathrm{~d}$ ).

From cytological and physiological evidence, Shanbaky et al. (1990 a), concluded that number of neurosecretory cells laden with secretion in newly emerged previtellogenic females (within $24 \mathrm{~h}$ ) and females during early vitellogenesis (1-2 
days) is relatively high and decrease in late vitellogenic (3 - 4 days $)$ and in postvitellogenic females (4- 7 days) where gonadotropic hormone reaches a maximum level in the female hemolymph.

Administration of Admiral to the females during periods of high neurosecretory cells releasing activity would be expected to add to the effect of endogenous $\mathrm{JH}$ and hence lowers or inhibits the releasing activity of neurosecretory cells of the treated females. However, application of exogenous JHA (Admiral) to females during periods of maximum titer of endogenous $\mathrm{JH}$ would be expected to induce an augmented effect on the developing ova inside the females which upset the normal embryonic development in the deposited eggs (Shanbaky et al., 1993). This argument may explain the relatively low effect of Admiral on the viability of the deposited eggs when applied to female tick on the day of emergence and its high effect when applied on $3^{\text {rd }}$ and $7^{\text {th }}$ day of emergence respectively.

However, the effect was more pronounced when hormonal material was applied to female during vitellogenesis (3 days) and before chorion formation and ovulation (7 days). Apparently, chorion act as a barrier that interferes with penetration of the hormonal material into egg.

\section{Late effect of JHA (Admiral) on postembryonic development of eggs obtained} from females treated at different periods of the reproductive cycle:

In the present study Admiral caused a delayed effect on the postembryonic stages of the eggs laid by the treated females of the tick Argas persicus. Hatched eggs give rise to larvae which suffered from a high mortality rate. This rate was also high at second nymphal instar followed by third nymphal instar.

The first observation of latent effect on postembryonic development was demonstrated by Riddiford and Williams (1967) in silk worm. They suggested that the late effect of juvenile hormone and juvenile hormone analogues on postembryonic development may indicate the ability of the hormonal material to interfere with the programming or latent storage of information for postembryonic development.

Application of JHAs to oocytes in the female ovaries may show latent effect on postembryonic development of several insect species such as Cimex lectularius (Radwan et al., 1984) and Musca domestica (Shanbaky et al., 1993).

The plant extract of neem seed oil Azadirachta indica induce a significant increase in mortality rates of newly hatched larvae of Hyalomma anatolicum excavatum after application on adult females (Abdel-Shafy and Zayed 2002). Melia azedarach extract caused mortality of Boophilus microplus larvae, $168 \mathrm{~h}$ after adult treatment (Borges et al., 2003).

The possibility of the persistence of the hormonal material in the insect throughout larval life was disproved by Riddiford (1970, 1971), rather, the applied JHA must have a direct effect on the embryo, or on the programming of the cells or on the programming of the corpora allata of the developing larva (Riddiford and Williams, 1967; Riddiford, 1970).

\section{Effect of direct application of JHA (Admiral) on viability of eggs by topical and dipping techniques:}

Topical application of different doses of Admiral, has a significant effect on the development of Argas persicus eggs treated at day of deposition.

Application of JHA (ZR - 515) to freshly laid eggs of Cimex lectularius blocked embryonic development during or after blastokinesis; and it prevents egg hatching when applied in higher doses, during the first three hours of deposition (Shaarawi et al., 1982). Topical application of adult females Boophilus microplus 
with Melia azedarach extract did not kill the adult females, but inhibit partially or totally egg productions and embryogenesis (Borges et al. 2003). Similar observation occurred, with Adham and Shoukry (1984), and Benskin and Vinson (1973).

On the other hand, topical application of JHI or JHA to newly laid eggs of Musca domestica has no effect on viability of treated eggs (Shanbaky et al., 1993), and application of fenoxycarb to Ixodes dammini eggs has no ovicidal effect on treated eggs (Slusser and Sonenshine, 1992).

In the present study, immersion of newly deposited eggs of Argas persicus in Admiral solution of different concentrations for $1 \mathrm{~min}$ have a highly significant effect in reducing egg viability. Dipping technique proved also to be effective in treatment of Acheta domestica eggs with dimataf and diflubenzuron that show a good ovicidal effect on treated eggs (Matolin and Chwakova, 1983), and the same was observed in treatment of Coleopteran eggs with JHA for 3 seconds (Walker and Bowas, 1970). Dipping of Phytoseiulus persimilis eggs in $100 \mathrm{ppm}$ of kenoprene, methoprene and hydroprene inhibit egg hatching by 100\% (Mandanalar and Kismali, 1994).

\section{REFERENCES}

Abdel-Shafy, S. and Zayed, A.A. (2002). In vitro acaricidal effect of plant extract of neem seed oil (Azadirachta indica) on egg, immature and adult stages of Hyalomma anatolicum excavatum (Ixodoidea: Ixodidae). Vet. Parasitol., 106(1): $\quad$ 89-96.

Adham, F.K. and Shoukry, A. (1984). Juvenile hormone analogues; effect on eggs of Aedes caspius pallas (Diptera: Culicidae). J. Egypt. Soc. Parasitol., 14(2): 525-530.

Bassal, T. T. M. (1974). Biochemical and physiological studies of certain ticks (Ixodidae). Activity of juvenile hormone analogues during embryogenesis in Hyalomma dromedarii Koch (Ixodidae). Z. Parasitenk., 45: 85-89.

Benskin, J. and Vinson, S.B. (1973). Factors affecting juvenile hormone analogue activity in the Tobacco budworms. J. Econ. Entomol., 66: 15-20.

Borges, L.M.F.; Ferri, P.H.; Silva, W.J.; Silva, W.C. and Silva, J.G. (2003). In vitro efficacy of extract of Melia azedarach against the tick Boophilus microplus. Med. Vet. Entomol., 17: 228-231.

Diehl, P.A.; Aeschliman, A. and Obenchain, F.D. (1982). Tick reproduction: oogenesis and reproduction. In: F.D. Obenchain and R. Galum (edes). The physiology of ticks. Pergamon press, Oxford, 277-350.

Gelbic, I. and Sehnal, F. (1973). Effect of juvenile hormone mimics on the codling moth Cydial pomonella (L.) (Lep., Olethreutidae). Bull. Ent. Res., 63: 7-15.

Hoogstraal, H. (1985). Argasid and nuttalliellid ticks as parasites and vectors. Adv. Parasitol., 24: 135-238.

Kaiser, M.N. (1966). The subgenus persicargas (Ixodoidea, Argasidae, Argas). 3. The life cycle of $A$. (P.) arboreus and a standardized rearing method for argasid ticks. Ann. Ent. Soc. Amer., 59: 496-502.

Kantakova, I. K.; Loffe, I. D. and Uspensky, I. V. (1976). Comparative evaluation of the effect of biologically active different group substances on engorged female Ixodes persulcatus P. Sch.(Acarina, Ixodidae). Med. Parazit. Moskva, 48: 49-55.

Loffe, I.D.; Uspensky, I.V.; Bessmertnaya, I.K. and Kachanko, N.I. (1977). Effect of synthetic juvenile hormone analogue on Ixodoidea. Zh. Obshch. Biol. 38: 885-892. (In Russian). 
Loffe, I.D. and Uspensky, I. V. (1979). Effect of juvenile hormone analogue on ixodid tick nymphs. Med. Parazit. Moskva, 48: 39- 46 (In Russian).

Mandanlar, N. and Kismali, S. (1994). Effects of some juvenile hormone analogues on the egg hatching and postembryonic development of Phytoseiulus persimilis Athias-Henriot (Acarina: Phytoseiidae). Ege. Uni. Ziraak. Fakuites, Bitlei. Kotuma. Bolumu. Izmir., 539-548: 25-28.

Mansingh, A. and Rawlins, S. C. (1977). Antigonadotropic action of insect juvenile analogues on the cattle tick, Boophilus microplus. Natuswissenschaften., 64: 41.

Matolin, S. and Chudakova, I.V. (1983). Ovicidal effects of diflubenzuron and dimatif on eggs of Acheta domestica (Orthoptera). Acta. Entomol. Bohemoslov., 80: 352-355.

Matalin, S. and Gelbic, I. (1975). The ovicidal and sterilant effects of juvenoids on the codling moth, Cydia pomonella (Lep., Tortricidae). Acta ent. Bohemoslov., 72(6): 360-369.

McDaniel, R. S. II and Oliver Jr, J.H. (1978). Effects of two juvenile hormone analogs and $\beta$-ecdysone on nymphal development, spermatogenesis and embryogensis in Dermacentor variabilis (Say) (Acari: Ixodidae). J. Parasitol. 64: 571-573.

Pound, J.M. and Oliver Jr, J.H. (1979). Evidence of a role for juvenile hormone in the reproduction of ticks. Science, 207: 355-357.

Radwan, W.A.M.; Shaarawi, F.A.I. and Soliman, S.A. (1984). Effects of juvenoids on some biological aspects of the bed bug, Cimex lectularius L. III. Late effect on postembryonic development. Bull. Soc. Ent. Egypte, 65: 319-331.

Rasa, C.G.; Meola, R.W. and Schenker, R. (2000). Effect of a new insect growth regulator, CGA-255"728, on the different stages of the cat flea (Siphonoptera: Pulicidae). J. Med. Entomol., 37(1): 141-145.

Riddiford, L.M. (1970). Effects of juvenile hormone on the programming of postembryonic development in eggs of silkworm, Hyalophora cecropia. Develop. Biol., 22: 249-263.

Riddiford, L.M. (1971). Juvenile hormone and insect embryogenesis. Mitt. Schweiz. Entomol. Oes., 44: 177-186.

Riddiford, L.M. and Williams, C.M. (1967). The effect of juvenile hormone analogues on the embryonic development of silkworms. Proc. Nat. Acad. Sci. U.S.A., 57: 595-601.

Shaarawi, F.A.I.; Radwan, W.A.M. and Soliman, S.A. (1981). Effects of juvenoids on some biological aspects of the bed bug, Cimex lectularius L. I. Effects on female fecundity. Bull. Fac. Sci., K.A.U, Jeddah, 5: 123-132.

Shaarawi, F.A.I.; Radwan, W.A.M. and Soliman, S.A. (1982): Effects of juvenoids on some biological aspects of the bed bug Cimex lectularius L. II. Effect on egg viability and embryogenesis. Bull. Fac. Sci., K.A.U, Jeddah, 6: 35-47.

Shanbaky, N.M.; El-Said, A. and Helmy, N. (1990 a). Changes in neurosecretory cell activity in female Argas (Argas) hermanni (Acari: Argasidae). J. Med. Entomol., 27: 975-998.

Shanbaky, N.M.; Mansour, M.M.; Main, A.J.; El-Said, A. and Helmy, N. (1990 d). Hormonal control of vitellogenesis in Argas hermanni (Acari: Argasidae). J.Med. Entomol., 27(6): 968-974.

Shanbaky, N.M.; Enan, R.A.; Radwan, W.A. and Hasaneen, H.E. (1993). Effect of juvenile hormone analogue on embryonic and postembryonic development of Musca domestica (L.) $18^{\text {th }}$ international conference for statistics, computer science, scientific and social applications, Cairo, Egypt, pp: 169-190. 
Slusser, J.H. and Sonenshine, D.E. (1992). Absence of ovicidal effects of fenoxycarb in the tick Ixodes dommini as observed by light, scanning and transmission electron microscopy. J. Med. Entomol., 29(1): 115-117.

Teel, P.D.; Donahue, W.A.; Strey, O.F. and Meola, R.W. (1996). Effects of pyriproxyfen on engorged females and newly oviposited eggs of the lone star tick (Acari: Ixodidae). J. Med. Entomol., 33(5): 721-725.

Walker, W.F. and Bowers, W.S. (1970). Synthetic juvenile hormone as potential coleopteran ovicides. J. Econ. Entomol. 68: 1231-1233.

\section{ARABIC SUMMARY}

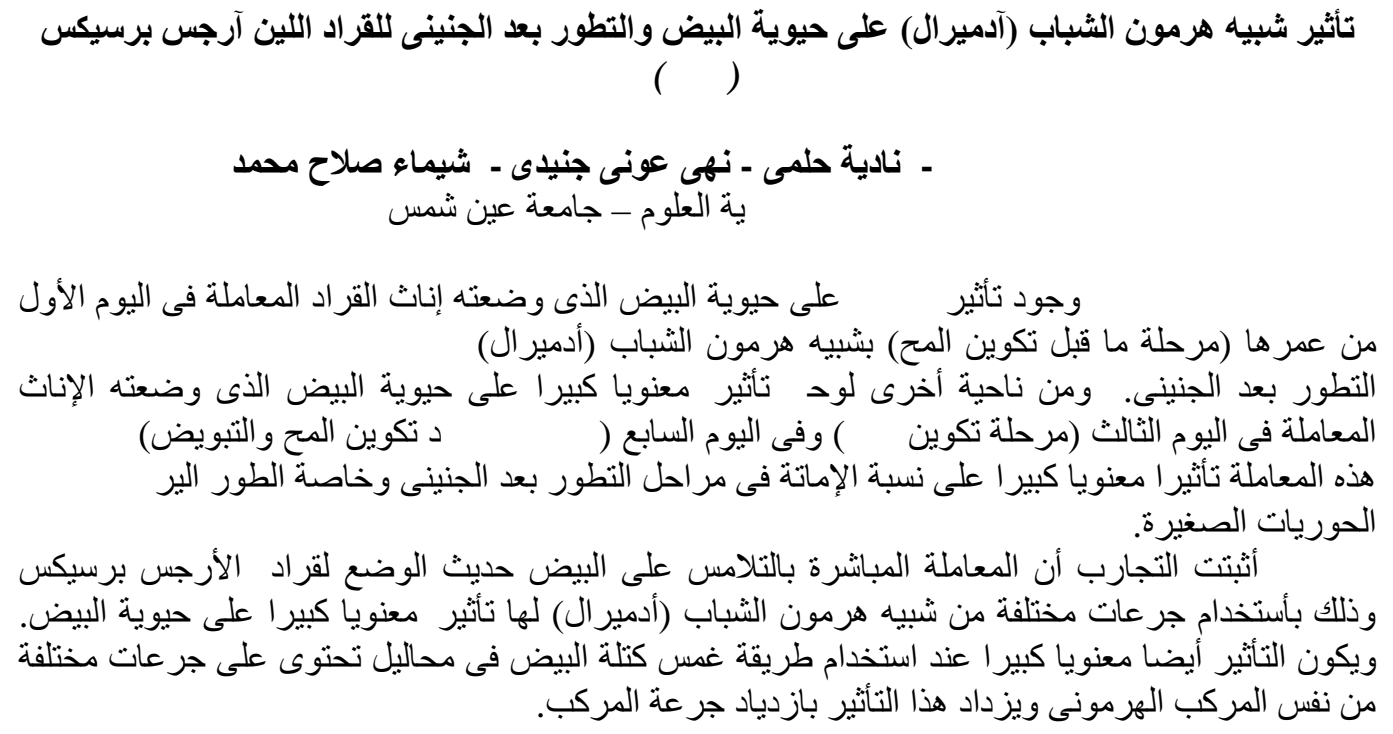

